\title{
MODIFIKASI MODEL PEMBELAJARAN SPORT EDUCATION BERBASIS KEJUARAAN UNTUK GURU PENJAS SMP
}

\author{
MODIVICATION A SPORT EDUCATION MODEL \\ FOR JUNIOR HIGH SCHOOL PHYSICAL EDUCATION TEACHERS
}

\author{
Wilian Dalton, Hari Amirullah Rachman \\ Dinas Pendidikan dan Olahraga Kabupaten Gunungkidul, Universitas Negeri Yogyakarta \\ willy_hockey_penjas@yahoo.com, harirachman@yahoo.com.au
}

\begin{abstract}
Abstrak
Penelitian ini bertujuan untuk modifikasi model pembelajaran sport education berbasis kejuaraan untuk guru penjas SMP, dalam bentuk buku panduan pelaksanaan model pembelajaran berbasis kejuaraan. Penelitian ini merupakan penelitian dan modifikasi. Pengembangan dilakukan mengacu pada model pengembangan Borg \& Gall dan Sugiyono dengan beberapa modifikasi menjadi lima tahap. Subjek uji coba dalam penelitian ini adalah siswa SMP 1 Panggang, SMP 1 Mlati dan MTs Banyusoca. Instrumen yang digunakan adalah lembar validasi untuk ahli dan praktisi penjas, lembar observasi, angket untuk penilaian guru dan angket untuk tanggapan siswa. Hasil penelitian menunjukkan bahwa: (1) Prosedur pengembangan melalui lima tahap, yaitu tahap studi pendahuluan, tahap desain produk, Tahap validasi ahli, tahap uji coba dan revisi produk dan tahap produk akhir. (2) Buku terdiri atas tiga bab, yaitu bab 1, pengenalan pembelajaran berbasis kejuaraan; bab 2, tata laksana pembelajaran berbasis kejuaraan; dan bab 3, penutup. (3) Hasil validasi menunjukkan buku panduan yang dikembangkan layak digunakan dengan kategori sangat tinggi. (4). Penilaian guru pendidikan jasmani terhadap kualitas buku panduan dengan rerata sebesar 16 (masuk dalam kategori sangat tinggi). Tanggapan siswa terhadap pelaksanaan pembelajaran sport education rerata sebesar 9,06 (masuk dalam kategori sangat tinggi). (5) Kesimpulannya buku panduan pelaksanaan model pembelajaran sport education layak untuk digunakan sebagai sumber belajar.
\end{abstract}

Kata kunci: modifikasi buku panduan, penjas, sport education model

\begin{abstract}
This study aims to develop the sport education model for junior high school physical education teachers, in the form of a handbook of sport education model.This was research and development study. The development was carried out by referring to the Borg \& Gall and Sugiyono which has been modified to become five stages. The research subjects were student of SMP 1 Panggang, SMP 1 Mlati and MTs Banyusoca. The data collection instrument included the expert and practitioner validation sheets, observation sheets, teacher evaluation questionnaires, and student response to the questionnaires.The Research findings on the development of sport education model are follows. (1) The development procedures cover five stages: the preliminary study, product design, expert and practitioner validation, small-scale try out, and field try out. (2) The handbook consist of three chapters: chapter 1, introduction to the sport education model; chapter 2, implementation of the sport education model; chapter 3, closing. (3) The result of the validation shows that the handbook were appropriate to use and is in the very high category. (4) Assessment by physical education teacher for the quality of handbook attains the mean score of 16, which is in a very high category. The student responses to the sport education model attains the score of 9,06 which is in a very high category. (5) The conclusion is that the handbook of implementation sport education model worth of using as a learning resource.
\end{abstract}

Keywords: modification of the handbook, physical education, sport education model 


\section{Pendahuluan}

Pendidikan merupakan kebutuhan manusia yang berlangsung seumur hidup. Melalui pendidikan diharapkan manusia dapat mengembangkan pengetahuan, keterampilan dan kreativitas untuk mencapai taraf hidup yang layak. Keberhasilan dibidang pendidikan sangat ditentukan dalam proses belajar mengajar. Proses belajar mengajar merupakan rangkaian kegiatan komunikasi antarmanusia yaitu orang yang mengajar disebut guru dan orang yang belajar disebut siswa.

Dalam proses belajar mengajar guru akan menghadapi siswa yang mempunyai karakteristik dan kemampuan yang berbeda-beda. Guru dalam proses belajar mengajar tidak akan pernah lepas dengan masalah hasil belajar siswanya, karena hasil belajar merupakan salah satu ukuran dari hasil kemampuan siswa dalam menerima pelajaran di sekolah. Membuat siswa dalam situasi belajar yang menyenangkan terlebih lagi untuk mencapai tujuan pembelajaran yang diharapkan bukanlah hal yang mudah. Guru harus menciptakan kondisi-kondisi tertentu sehingga siswa nyaman dalam belajar.

Pendidikan memiliki sasaran pedagogis, oleh karena itu pendidikan tidak lengkap tanpa adanya pendidikan jasmani. Gerak sebagai aktivitas jasmani adalah dasar bagi manusia untuk mengenal dunia dan dirinya sendiri yang secara alami berkembang searah dengan perkembangan zaman. Pendidikan jasmani merupakan media untuk mendorong pertumbuhan fisik, perkembangan psikis, keterampilan motorik, pengetahuan dan penalaran, penghayatan nilai-nilai, serta pembiasaan pola hidup sehat yang bermuara untuk merangsang pertumbuhan dan perkembangan kualitas fisik dan psikis yang seimbang.

Pendidikan jasmani memiliki peran yang strategis dalam kurikulum. Pendidikan jasmani, olahraga, dan kesehatan bertujuan agar peserta didik memiliki kemampuan sebagai berikut (Mendiknas, 2006, p.513): (1) Mengembangkan keterampilan pengelolaan diri dalam upaya pengembangan dan pemeliharaan kebugaran jasmani serta pola hidup sehat melalui berbagai aktivitas jasmani dan olahraga yang terpilih; (2) Meningkatkan pertumbuhan fisik dan pengembangan psikis yang lebih baik; (3) Meningkatkan kemampuan dan keterampilan gerak dasar; (4) Meletakkan landasan karakter moral yang kuat melalui internalisasi nilai-nilai yang terkandung di dalam pendidikan jasmani, olahraga dan kesehatan; (5) Mengembangkan sikap sportif, jujur, disiplin, bertanggung jawab, kerja sama, percaya diri dan demokratis; (6) Mengembangkan keterampilan untuk menjaga keselamatan diri sendiri, orang lain dan lingkungan; (7) Memahami konsep aktivitas jasmani dan olahraga di lingkungan yang bersih sebagai informasi untuk mencapai pertumbuhan fisik yang sempurna, pola hidup sehat dan kebugaran, terampil, serta memiliki sikap yang positif.

Dalam pembelajaran di sekolah, pendidikan jasmani menghadapi berbagai hambatan. Hambatan terdiri dari berbagai faktor, yaitu faktor kurikulum, faktor guru, faktor siswa, hingga faktor sarana prasarana. Hambatan haruslah dilihat sebagai pelecut untuk berprestasi lebih baik.

Gambaran yang bersifat mendunia adalah (1) penilaian diri rendah dari profesi pendidikan jasmani, (2) alokasi yang lebih besar untuk olahraga kompetitif dan elit dibandingkan dengan untuk keperluan pendidikan jasmani, (3) ketidakmampuan pendidikan jasmani untuk mengkomunikasikan pesan yang bermakna kepada setiap lapisan masyarakat (warga masyarakat pada umumnya, profesional, politisi, pemimpin organisasi, orangtua). Selain itu masih ketimpangan gender, seperti juga partisipasi orang cacat yang masih terbatas karena kekurangan fasilitas dan pemisahan anak normal dan anak cacat menjadi sekolah khusus (Nuruddin, 2011, p.14).

Salah satu tantangan pendidikan jasmani adalah menentukan orientasi kurikulum yang tepat. Setidaknya ada dua konsep tujuan pendidikan jasmani. Pertama, pendidikan jasmani dikonsepsikan secara biologis. Cara pandang konsep biologis ini menyatakan bahwa pendidikan jasmani merupakan pelatihan dari jasmani, tubuh merupakan sebuah mesin instrumen, artinya tubuh adalah suatu kumpulan instrumen yang memiliki fungsinya masing-masing dan bekerja untuk satu keseluruhan item. Pembelajaran dalam konsep ini akan menekankan pada latihan-latihan fisik, penguasaan gerak, teknik maupun latihan peningkatan kebugaran jasmani. Pembelajaran lebih menekankan pada tugas latihan. Guru pendidikan jasmani akan mengevaluasi hasil pembelajaran dengan cara-cara semacam tes kebugaran jasmani.

Cara pandang kedua tentang pendidikan jasmani berasal dari konsep pedagogis, pendidikan melalui gerak. Konsep pedagogis memiliki konsep di mana tubuh sebagai entry ke 
arah pemikiran, karakter dan kepribadian. Pendidikan jasmani menurut konsep ini adalah mata pelajaran yang berfungsi untuk mendidik atau membentuk individu, bergerak untuk belajar. Output utamanya adalah membentuk pribadi luhur pada siswa (Caly, 2004, p.3).

Pembelajaran pendidikan jasmani harus dilaksanakan secara kreatif. Namun realitas di lapangan, banyak guru pendidikan jasmani hanya menggunakan model pembelajaran yang monoton. Guru telah merasa puas dengan cara mengajar yang telah rutin dilakukan selama bertahun-tahun dan secara umum kurang dalam pelatihan formal pengembangan kurikulum (Alexander dan Penney, 2005, p.287). Rutinitas dan kejenuhan membuat guru penjas sulit berkembang dan mengalami kemacetan dalam pertumbuhan intelektual. Berdasarkan pengamatan peneliti di lapangan, pembelajaran pendidikan jasmani dewasa ini cenderung dilaksanakan dengan metode mengajar direct instruction dan berpusat pada guru. Guru seharusnya mampu memahami karakteristik siswa agar dapat menemukan pendekatan pembelajaran yang sesuai.

Guru pendidikan jasmani tidak boleh terjebak dalam rutinitas kerja dan meninggalkan tanggung jawab profesionalnya. Rutinitas lebih dekat dengan gagasan status quo daripada dinamika perubahan dan kreativitas. Rutinitas kerja akan menyebabkan kemandulan kreativitas serta inovasi guru dalam mengajar. Guru Pendidikan Jasmani dituntut selalu berimprovisasi dalam meningkatkan kinerjanya.

Guru harus menguasai gaya mengajar yang bervariasi, mengingat bahwa (a) siswa terdiri atas populasi yang berbeda, (b) pendidikan jasmani memiliki tujuan pembelajaran yang kompleks mulai dari ranah psikomotor, kognitif hingga aspek sosial, (c) materi pembelajaran pendidikan jasmani yang sangat spesifik. Siswa belajar dengan cara yang berbeda, datang dari latar belakang budaya yang berbeda, dan memiliki tingkat pengalaman gerak yang berbeda. Perbedaan ini menimbulkan perbedaan penanganan dan perbedaan kebutuhan untuk masingmasing siswa. Sayangnya perbedaan-perbedaan ini seringkali diabaikan oleh guru pendidikan jasmani (Byra, 2006, p.449).

Materi pembelajaran pendidikan jasmani terlalu luas namun hanya dipelajari di permukaannya saja. Berbagai cabang olahraga harus dikuasai oleh siswa, namun alokasi waktu yang sedikit dan sarana prasarana yang terbatas menyebabkan pengetahuan siswa tentang sebuah cabang olahraga menjadi sangat kurang
(Siedentop, 2004, p.3). Alokasi waktu dalam kurikulum penjas SMP di Indonesia sebanyak tiga jam per minggu (Kemendiknas, 2013, p.2). Waktu tersebut sangat kurang mengingat banyaknya materi pembelajaran yang harus disampaikan. Guru harus menyusun strategi pembelajaran yang tepat agar siswa mampu menguasai materi pembelajaran dengan alokasi waktu yang terbatas tersebut.

Pembelajaran penjas di Sekolah Menengah Pertama (SMP) memegang kunci penting dalam tahap perkembangan siswa, baik afektif, kognitif, maupun psikomotorik. Secara umum karakteristik siswa SMP telah mampu bekerja sama dalam tim dengan baik dan jiwa kepemimpinan mulai muncul. Pada usia ini guru haruslah memaksimalkan potensi yang dimiliki siswa. Namun pada kenyataannya para guru lebih senang mengajarkan teknik-teknik olahraga yang sering terpisah dari suasana permainan sebenarnya, atau jika pun melakukan permainan, permainan tersebut tidak sesuai dengan hakikat kemampuan anak serta kehilangan nilai-nilai keolahragaannya. Pembelajaran penjas tidak memberikan pengalaman yang lengkap pada anak dalam berolahraga (Siedentop, 1994, p.116).

Dalam rangka membantu pencapaian tujuan penjas di SMP, seorang guru bertugas merencanakan, memilih dan mengorganisir materi pembelajaran. Dalam pelaksanaan penyajian proses pembelajaran, guru memilih model pembelajaran yang sesuai dengan tingkat kematangan, kekuatan, konsentrasi, pertumbuhan dan perkembangan siswa. Peran serta guru yang profesional sangat berperan dalam pelaksanaanya. Jika guru tidak mampu menghadirkan pembelajaran yang efektif, maka akan menyebabkan hilangnya peluang emas untuk meraih keuntungan semaksimal mungkin dari pengajaran pendidikan jasmani sebagai medium pendidikan (Rukmana, 2008, p.24).

Dalam sistem kurikulum di Indonesia saat ini, sesungguhnya telah memberi kesempatan guru untuk berkreasi. Dalam kurikulum tingkat satuan pendidikan, guru diberi keleluasaan untuk merencanakan pembelajaran sesuai kondisi sekolah masing-masing. Modifikasi model pembelajaran sangat selaras dengan tuntutan kurikulum tingkat satuan pendidikan.

Pendidikan mencerminkan masyarakat secara menyeluruh. Perubahan yang ada di masyarakat menuntut pendidikan untuk berubah pula. Model pembelajaran yang kreatif dan inovatif adalah upaya guru untuk menciptakan 
pembelajaran yang lebih baik. Revitalisasi peran pendidikan jasmani di sekolah haruslah segera dilakukan. Salah satu upaya ke arah perbaikan adalah melalui rekayasa perbaikan model pembelajaran.

Kurikulum pendidikan jasmani di Indonesia saat ini menggunakan kurikulum tingkat satuan pendidikan (KTSP). Undang-undang Republik Indonesia Nomor 20 Tahun 2005 tentang Sistem Pendidikan Nasional mengamanatkan satuan pendidikan untuk menyusun kurikulum tingkat satuan pendidikan (KTSP) dengan mengacu pada standar isi (SI) dan standar kompetensi lulusan (SKL) serta berpedoman pada panduan yang disusun oleh BSNP. Dalam KTSP, guru diberi keleluasaan untuk melakukan inovasi pendidikan yang berpusat pada potensi, perkembangan, kebutuhan, dan kepentingan peserta didik dan lingkungannya. Inovasi model pembelajaran pendidikan jasmani menggunakan model pembelajaran baru sangat terbuka untuk dilakukan. Salah satu model pembelajaran yang belum banyak digunakan di Indonesia adalah sport education.

Sport education yang sebelumnya diberi nama play education dikembangkan oleh Daryl Siedentop. Model ini berorientasi pada nilai rujukan disciplinary mastery (penguasaan materi), dan merujuk pada model kurikulum sport socialization. Enam karakteristik model sport education adalah: musim, anggota team, pertandingan formal, pertandingan puncak, catatan hasil, perayaan hasil kompetisi (Siedentop, 2004, p.5).

Model pembelajaran sport education belumlah tepat untuk diterapkan secara langsung. Perlu pengembangan agar sesuai dengan karakteristik pembelajaran di Indonesia. Di sisi lain, mayoritas guru pendidikan jasmani belum mengenal model sport education dengan baik. Hal ini diakibatkan oleh belum adanya buku panduan pelaksanaan sport education yang mudah dipahami, mudah diterapkan dan berbahasa Indonesia. Akibat berbagai kendala tersebut, penerapan sport education di Indonesia belum bisa dilakukan secara luas. Solusi yang harus dilakukan adalah melakukan modifikasi model pembelajaran sport education agar mudah diterapkan. Modifikasi model pembelajaran dituangkan dalam sebuah buku panduan pelaksanaan pembelajaran.

Dari latar belakang masalah tersebut, dapat disimpulkan bahwa penelitian modifikasi model pembelajaran sport education berbasis kejuaraan adalah sebuah agenda yang mendesak untuk dilakukan. Penulis selanjutnya berinisiatif untuk meneliti tentang "Modifikasi model Pembelajaran Sport education Berbasis Kejuaraan untuk Guru Penjas SMP”.

\section{Metode}

Jenis Penelitian

Penelitian ini menggunakan metode penelitian dan pengembangan. Menurut Sujadi (2003, p.164) penelitian dan pengembangan atau research and development adalah suatu proses atau langkah-langkah untuk mengembangkan suatu produk baru, atau menyempurnakan produk yang telah ada, yang dapat dipertanggungjawabkan. Produk tersebut tidak selalu berbentuk benda atau perangkat keras (hardware), seperti buku, modul, alat bantu pembelajaran di kelas atau di laboratorium, tetapi bisa juga perangkat lunak (software), seperti program komputer untuk pengolahan data, pembelajaran di kelas, perpustakaan atau laboratorium, ataupun model-model pendidikan, pembelajaran, pelatihan, bimbingan, evaluasi, dan manajemen.

Pengembangan dalam penelitian ini adalah memodifikasi model pembelajaran sport education agar lebih sesuai dengan kondisi kurikulum dan karakteristik pembelajaran pendidikan jasmani di Indonesia. Model pembelajaran disusun dalam sebuah buku panduan yang mudah dipahami dan mudah dilaksanakan guru pendidikan jasmani SMP.

Waktu dan Tempat Penelitian

Studi pendahuluan dilakukan pada bulan Desember 2012 hingga bulan Januari 2013. Studi pendahuluan dilaksanakan di SMP N 1 Sleman dan SMP N 1 Purwosari, Gunungkidul.

Uji coba skala skala kecil dilakukan pada bulan April dan Mei tahun 2013. Uji coba dilakukan di SMP N 1 Panggang dengan alamat Panggang I, Giriharjo, Panggang, Gunungkidul, DIY.

Uji coba skala skala besar dilakukan pada bulan Mei tahun 2013. Uji coba dilakukan di dua sekolah yaitu SMP N 1 Mlati dan MTs Banyusoca.

\section{Subjek Penelitian}

Subjek coba kelompok kecil adalah guru dan siswa SMP N 1 Panggang, Girimulyo, Panggang, Gunungkidul. Subjek uji skala besar adalah guru dan siswa SMP N 1 Mlati, dan MTs Banyusoca Playen. 
Prosedur

Prosedur pengembangan dalam penelitian ini menggunakan prosedur adaptasi yang dilakukan Sugiyono (2010, p.316). Prosedur yang diadaptasikan tersebut meliputi lima tahap yaitu (1) tahap studi pendahuluan, (2) desain produk dan (3) validasi (4) uji coba dan revisi produk, dan (5) Produk akhir.

\section{Tahap Studi Pendahuluan}

Tahap ini merupakan tahap pertama atau persiapan untuk pengembangan. Tahap ini terdiri dari studi kepustakaan dan suvei lapangan, pada tahap studi kepustakaan, peneliti melakukan kajian terhadap konsep-konsep atau teori-teori yang bekenaan dengan permainan untuk pemanasan yang akan dikembangkan. Selain itu juga dilakukan kajian terhadap hasilhasil penelitian yang berkenaan dengan pembelajaran penjas.

Survei lapangan dilaksanakan untuk mengetahui perencanaan dan pelaksaan pembelajaran penjas. Survei ini dilakukan dengan wawancara, studi dokumenter dan observasi lapangan yaitu pengamatan pada waktu guru mengajar. Observasi di lapangan ini bertujuan untuk mengetahui proses pembelajaran yang dilakukan oleh guru, untuk melihat karakteristik dari peserta didik dalam mengikuti proses pembelajaran, serta analisis kebutuhan produk yang dibutuhkan guru pendidikan jasmani.

\section{Tahap Desain Produk}

Berdasarkan pada studi kepustakaan mengenai dasar-dasar teori dan konsep mengenai permainan untuk pemanasan serta survei lapangan, maka peneliti menyusun draft awal yaitu model yang akan dikembangkan. Pada tahap ini langkah-langkah pengembangan dirancang dengan didasarkan analisis yang dibutuhkan.

\section{Tahap Validasi}

Draft poduk yang telah dihasilkan kemudian di nilai oleh ahli sehingga diketahui apakah draft produk yang diciptakan layak dipakai. Kegiatan ini dilakukan oleh ahli materi pendidikan jasmani dan seorang praktisi penjas.

\section{Tahap Uji Coba dan Revisi Produk}

Draft poduk yang telah dihasilkan kemudian diuji coba untuk pengembangan lebih lanjut. Uji coba dilakukan untuk menguji kelayakan produk. Uji coba dilakukan dalam skala kecil dan skala besar. Hasil ini kemudian sebA- gai dasar evaluasi untuk memperbaiki produk sehingga dihasilkan produk akhir.

\section{Produk Akhir}

Berdasarakan revisi dan masukan selama uji coba, maka kemudian disusun produk kahir yang layak untuk digunakan secara massal.

\section{Teknik Analisis Data}

Teknik analisis data kualitatif menggunakan triangulasi. Triangulasi adalah teknik pemeriksaan keabsahan data yang memanfaatkan sesuatu yang lain di luar data itu untuk keperluan pengecekan atau sebagai pembanding terhadap data itu. Metode triangulasi data dilakukan dengan beberapa cara; (1) Membandingkan data hasil pengamatan dengan data hasil wawancara. (2) Membandingkan apa yang dikatakan seseorang tentang situasi terbuka dan tertutup. (3) Membandingkan pendapat dan perspektif seseorang dengan orang lain. (4). Membandingkan hasil wawancara dengan isi suatu dokumen yang berkaitan (Sugiyono, 2010, p.112).

Sementara analisis data kuantitatif menganalisis lembar validasi dan kuesioner siswa. Adapun langkah-langkah yang digunakan untuk memenuhi kriteria kualitas terhadap produk adalah sebagai berikut. (1) Data skor yang diperoleh dari validator dan kuesioner direkap. (2) Melakukan pengkategorian skor masingmasing variabel.

\section{Hasil Penelitian dan Pembahasan}

Tahap Studi Pendahuluan

Tahap ini merupakan persiapan pengembangan buku panduan pelaksanaan model pembelajaran sport education. Tahap ini terdiri atas studi pustaka dan survey lapangan. Studi lapangan dilakukan pada bulan Desember 2012 hingga bulan Januari 2013. Studi pendahuluan dilaksanakan di SMP 1 Sleman dan SMP 1 Purwosari, Gunungkidul. Studi lapangan menunjukkan bahwa guru mengajar menggunakan model direct teaching atau pengajaran langsung. Pembelajaran berpusat pada guru.

Studi pendahuluan di SMP 1 Sleman dan SMP 1 Purwosari mengungkapkan bahwa guru pendidikan jasmani belum mengenal model sport education. Hal ini diakibatkan oleh belum adanya buku panduan pelaksanaan sport education yang mudah dipahami, practicable dan berbahasa Indonesia. Kebanyakan buku panduan pelaksanaan sport education sulit dipa- 
hami karena berbahasa Inggris. Situasi tersebut mengakibatkan pelaksanaan sport education di Indonesia belum bisa dilakukan secara luas. Perlu pengenalan model ini kepada guru-guru pendidikan jasmani, serta modifikasi dan pengembangan sebuah buku panduan pelaksanaan dengan kata-kata yang mudah dipahami, agar model ini mampu dilaksanakan sebagai model alternatif pembelajaran pendidikan jasmani di sekolah.

Studi pustaka menunjukkan bahwa terjadi kesenjangan antara kebijakan resmi dengan implementasi dan praktik. Pelaksanaan pembelajaran tidak sesuai dengan status legal dan nilai pendidikan jasmani dalam kaitannya dengan alokasi waktu dalam kurikulum (Nurrudin, 2011, p.13). Guru pendidikan jasmani mengajar tidak sesuai dengan skenario pembelajaran dalam RPP dan silabus, serta kurang dalam pelatihan formal pengembangan kurikulum. Guru pendidikan jasmani haruslah melakukan perbaikan proses belajar mengajar agar mampu mencapai standar kompetensi lulusan yang ditentukan. Salah satu upaya ke arah perbaikan adalah melalui rekayasa perbaikan model pembelajaran. Salah satu model pembelajaran yang belum banyak digunakan di Indonesia adalah sport education.

Studi pendahuluan menunjukkan bahwa kebutuhan guru pendidikan jasmani akan perbaikan kualitas pembelajaran adalah agenda yang mendesak. Buku panduan pelaksanaan pembelajaran sport educatation adalah salah satu upaya yang dilakukan guru untuk mencapai standar kompetensi lulusan yang ditetapkan kurikulum.

\section{Tahap Desain Produk}

Berdasarakan studi kepustakaan mengenai dasar-dasar teori model pembelajaran sport education, selanjutnya peneliti menentukan tujuan pengembangan produk, memilih cakupan materi, mencari bahan materi dan beberapa hal lainnya yang terkait dengan pengembangan produk.

Peneliti selanjutnya menyusun draft awal produk. Produk tersebut berupa buku panduan pelaksanaan model pembelajaran sport education. Buku disusun dengan kata-kata yang sederhana, mudah dipahami dan mudah dipraktekkan. Modifikasi model pembelajaran antara lain: (a) Materi pembelajaran. Materi pembelajaran dalam model sport education berbasis kejuaraan memasukkan unsur-unsur olahraga tradisional, yaitu Kasti, Sepaktakraw, Gobak
Sodor, lomba lari Bakiak dan Egrang; (b) Panjang musim. Panjang musim disesuaikan dengan kalender pendidikan di Indonesia. Panjang musim yang disarankan adalah delapan pertemuan. Jika guru telah menyelesaikan musim sepakbola, guru berlanjut pada meteri selanjutnya, misalnya bolavoli; (c) Penggabungan sport education dengan kurikulum berbasis kompetensi. Tidak semua materi diajarkan menggunakan sport education. Materi yang diajarkan dengan sport education adalah olahraga beregu. Materi lain disampaikan di akhir semester, dengan model pembelajaran biasa; (d) Penggunakan istilah berbahasa Indonesia. Berbagai istilah asing diterjemahkan dalam bahasa Indonesia tanpa merubah makna dari istilah tersebut. Istilah sport education diterjemahkan secara bebas menggunakan istilah Pembelajaran Berbasis Kejuaraan.

Desain produk dilakukan pada bulan Februari hingga Maret tahun 2013. Desain produk ini mengacu pada dua buku utama sport education, yaitu Quality PE Through Positive Sport Experience Sport education (Siedentop, 1994) dan Complete Guide to Sport education (Siedentop, Hastie, Van Der Mars, 2004). Namun secara umum buku panduan yang disusun bukanlah terjemahan langsung dari kedua buku diatas, karena peneliti melakukan pengembangan sesuai dengan karakteristik pendidikan jasmani di Indonesia.

Draft awal produk terdiri atas tiga bab, yaitu karakteristik sport education, tata laksana sport education dan penutup.

Uji Coba Skala Kecil

Uji coba skala skala kecil dilakukan pada bulan April dan Mei tahun 2013. Uji coba dilakukan di SMP 1 Panggang dengan alamat Panggang I, Giriharjo, Panggang, Gunungkidul, DIY. Kelas yang digunakan sebagai subjek uji coba adalah kelas VII D dengan jumlah siswa sebanyak 31 siswa. Guru pendidikan jasmani yang melaksakan pembelajaran dalam uji coba skala kecil adalah Sukardi, S.Pd. Praktisi Penjas melakukan pengamatan terhadap pembelajaran yang dilakukan. Praktisi penjas tersebut adalah Sutriyadi, S.Pd.

Sebelum melakukan uji coba model, peneliti terlebih dahulu berdiskusi dengan guru yang bersangkutan. Dalam pertemuan ini, peneliti menyerahkan buku panduan. Guru kemudian memahami dan menelaah buku panduan pelaksanaan Pembelajaran Berbasis Kejuaraan. Setelah memahami, guru lalu mencoba menyu- 
sun rencana pembelajaran yang menggunakan model sport education.

Karena keterbatasan waktu, dalam uji coba skala kecil ini guru hanya merencanakan pembelajaran selama empat kali pertemuan. Jadwal latihan dilakukan di luar jam pelajaran, yang jadwalnya disusun oleh rapat tim. Sistem pertandingan yang digunakan adalah setengah kompetisi. Standar kompetensi yang diajarakan adalah; Memraktikkan berbagai keterampilan permainan olahraga dalam bentuk sederhana dan nilai-nilai yang terkandung di dalamnya. Kompetensi dasar; mempraktikkan keterampilan bermain salah satu permainan dan olahraga beregu bola besar serta nilai kerja sama, kejujuran, menghargai, semangat, dan percaya diri. Materi yang dipilih adalah permainan sepaktakraw. Berikut adalah skenario pembelajaran yang disusun oleh guru pendidikan jasmani Sukardi, S.Pd.

Dalam musim pertandingan yang disebut Piala SMP Panggang ini, kelas yang berjumlah 31 anak dibagi dalam 4 tim. Tim dibagi dengan sistem undian dengan terlebih dahulu di kelompokkan berdasarkan kemampuan psikomotornya. Berikut adalah pembagian tim tersebut.

Hasil pertandingan Piala SMP Panggang menunjukkan bahwa tim Satria berhasil menjadi juara karena memperoleh tiga kali kemenangan. Pemain terbaik yang dipilih oleh rekan-rekan sekelas dan masukkan dari guru adalah Nurdiyanto. Hari terakhir pertandingan ditutup dengan pengumuman tim juara dan pengumuman pemain terbaik. Karena keterbatasan waktu dan biaya, puncak pertandingan dan festivity dilakukan dengan sangat sederhana.

Berdasarkan uji coba skala kecil, diperoleh data bahwa secara umum siswa merasa senang dengan model pembelajaran yang telah dilakukan. Hal ini dibuktikan dengan hasil angket yang disebar kepada 31 siswa diperoleh hasil 76\% masuk kategori sangat baik, dan 14\% dalam kategori baik.

Guru pendidikan jasmani berpendapat model ini sangat menarik untuk digunakan. Pada tahun ajaran selanjutnya, guru yang bersangkutan akan mencoba menggunakan model sport education dengan waktu yang lebih panjang dan sistem kompetisi penuh. Hasil instrument yang diberikan kepada guru menunjukkan bahwa buku panduan masuk dalam kategori sedang dan model pembelajaran masuk dalam kategori baik.
Masukan yang diberikan guru penjas selama uji coba skala kecil adalah: (1) Panjang musim harus disesuaikan dengan program sekolah yang telah tercantum dalam kalender pendidikan; (2) Buku panduan harus mencantumkan kelebihan dan kekurangan sport education; (3) Buku panduan mencantumkan kendala-kendala yang mungkin dihadapi dalam pelaksanaannya serta solusi.

\section{Uji Coba Skala Besar}

Uji coba skala skala besar dilakukan pada bulan Mei tahun 2013. Uji coba dilakukan di dua sekolah yang memiliki karakteristik sangat berbeda. Sekolah pertama adalah SMP 1 Mlati dengan alamat Tirtoadi, Mlati Sleman. Sekolah ini terletak di daerah pinggiran kota dengan fasilitas olahraga yang cukup baik. Guru pendidikan jasmani yang melaksakan pembelajaran dalam uji coba skala besar di SMP 1 Mlati adalah Jamhari, S.Pd.Jas. beliau adalah seorang guru senior dengan masa kerja 30 tahun lebih.

Sekolah kedua yang digunakan dalam uji coba skala besar adalah MTs Banyusoca Paliyan. Sekolah ini terletak di daerah yang termasuk daerah terpencil di Gunungkidul. Fasilitas olahraga yang dimiliki cukup terbatas. Guru pendidikan jasmani yang melaksanakan pembelajaran dalam uji coba skala besar adalah Ruswantini, S.Pd.Jas. Beliau adalah seorang guru muda yang memiliki integritas tinggi dan semangat dalam pengembangan kemampuan keprofesionalan yang masih baik.

Sebelum melakukan uji coba model, peneliti terlebih dahulu berdiskusi dengan kedua guru yang bersangkutan. Dalam pertemuan ini, peneliti menyerahkan buku panduan. Guru kemudian memahami dan menelaah Buku panduan pelaksanaan Pembelajaran Berbasis Kejuaraan. Setelah memahami, guru lalu mencoba menyusun Rencana Pelaksanaan Pembelajaran yang menggunakan model sport education. Pengambilan data ini dilakukan dalam rentang waktu yang hampir bersamaan, yaitu pada bulan Mei hingga awal bulan Juni.

Kejuaraan di SMP 1 Mlati disebut Piala Mlati 1, sementara di MTs Banyusoca disebut Piala Banyusoca. Kedua kejuaraan ini memiliki skenario pembelajaran yang cukup mirip, meskipun secara umum peneliti membiarkan guru untuk berkreasi berdasarkan situasi dan kondisi sekolah yang bersangkutan. 


\section{Hasil Uji Coba di SMP 1 Mlati}

Kelas yang digunakan sebagai subjek uji coba adalah kelas XII C dengan jumlah siswa sebanyak 35 siswa. Sama halnya dengan uji coba skala kecil, dalam uji coba skala besar ini guru hanya merencanakan pembelajaran selama empat kali pertemuan. Hal ini di sebabkan karena keterbatasan waktu dan masa hari efektif yang hampir habis. Jadwal latihan dilakukan di luar jam pelajaran, yang jadwalnya disusun oleh rapat tim. Sistem pertandingan yang digunakan adalah setengah kompetisi. Standar kompetensi yang diajarakan adalah: mempraktikkan berbagai keterampilan permainan olahraga dalam bentuk sederhana dan nilai-nilai yang terkandung di dalamnya. Kompetensi dasar dasar yang sampaikan adalah: mempraktikkan keterampilan bermain salah satu permainan dan olahraga beregu bola besar serta nilai kerja sama, kejujuran, menghargai, semangat, dan percaya diri.

Sistem pertandingan yang digunakan adalah setengah kompetisi. Materi pembelajaran yang dipilih dalam kedua subjek coba sama yaitu permainan sepakbola. Berikut adalah skenario pembelajaran yang disusun oleh guru pendidikan jasmani Jamhari, S.Pd.Jas.

Sebelum kejuaraan dimulai, terlebih dahulu tim dibagi. Tim dibagi dengan sistem undian dengan terlebih dahulu dikelompokkan berdasarkan kemampuan psikomotornya. Dalam pembagian tim, guru penjas SMP 1 Mlati yang bertugas mengelompokkan siswa berdasarkan kemampuan psikomotornya. Guru berperan paling utama karena guru tersebut yang mengetahui kemampuan siswanya. Berikut adalah pembagian tim di SMP 1 Mlati:

Berdasarkan pembagian tim tersebut, empat tim selanjutnya bertanding dengan sistem setengah kompetisi.

Hasil pertandingan Piala Mlati menunjukkan bahwa tim Yo United berhasil menjadi juara karena memperoleh tiga kali kemenangan. Pemain terbaik yang dipilih oleh rekan-rekan sekelas dan masukkan dari guru adalah Fata. Hari terakhir pertandingan ditutup dengan mengumumkan tim juara dan pengumuman pemain terbaik. Karena keterbatasan waktu dan biaya, puncak pertandingan dan festivity dilakukan dengan sangat sederhana.

Berdasarkan uji coba skala besar, diperoleh data bahwa secara umum siswa merasa senang dengan model pembelajaran yang telah dilakukan. Hal ini dibuktikan dengan hasil angket yang disebar kepada 35 siswa diperoleh hasil rerata sebesar 9,14 dan masuk dalam kategori baik. Mayoritas siswa merasa senang melaksanakan pembelajaran. Namun yang patut di catat, sebanyak delapan anak atau 22,8\% menyatakan bahwa pembelajaran dengan model sport education tidak meningkatkan kualitas gerak atau kemampuan psikomotorik mereka.

Guru pendidikan jasmani berpendapat model sport education sangat menarik untuk digunakan. Pada tahun ajaran selanjutnya, guru yang bersangkutan akan mencoba menggunakan model sport education dengan waktu yang lebih panjang dan sistem kompetisi penuh. Hasil instrument yang diberikan kepada guru menunjukkan bahwa buku panduan masuk dalam kategori baik dan model pembelajaran masuk dalam kategori baik.

\section{Hasil Uji Coba di MTs Banyusoca}

Subjek coba kedua skala besar kedua adalah MTs Banyusoca dengan alamat Banyusoca, Playen, Gunungkidul. Sekolah ini terletak di daerah yang cukup terpencil dan susah dijangkau. Fasilitas yang dimiliki sekolah ini kurang memadai, dengan kontur tanah yang kurang rata dan licin diwaktu hujan.

Kelas yang digunakan sebagai subjek coba adalah kelas XII A dengan jumlah siswa 27 anak. Sama halnya dengan uji coba skala kecil, dalam uji coba skala besar ini guru hanya merencanakan pembelajaran selama empat kali pertemuan. Hal ini di sebabkan karena keterbatasan waktu dan masa hari efektif yang hampir habis. Jadwal latihan dilakukan di luar jam pelajaran, yang jadwalnya disusun oleh rapat tim. Sistem pertandingan yang digunakan adalah setengah kompetisi. Standar kompetensi yang diajarakan adalah; Mempraktikkan berbagai keterampilan permainan olahraga dalam bentuk sederhana dan nilai-nilai yang terkandung di dalamnya. Kompetensi dasar; Mempraktikkan keterampilan bermain salah satu permainan dan olahraga beregu bola besar serta nilai kerjasama, kejujuran, menghargai, semangat, dan percaya diri.

Materi yang dipilih dalam kedua subjek coba sama yaitu permainan sepakbola. Sebelum kejuaraan dimulai, terlebih dahulu tim dibagi. Tim dibagi dengan sistem undian dengan terlebih dahulu dikelompokkan berdasarkan kemampuan psikomotornya. Berikut adalah pembagian tim di MTs Banyusoca:

Hasil pertandingan Piala Mlati menunjukkan bahwa tim Wota berhasil menjadi juara 
karena memperoleh nilai tujuh, hasil dua kali menang dan sekali draw. Pemain terbaik yang dipilih oleh rekan-rekan sekelas dan masukkan dari guru adalah Nurtaufik. Hari terakhir pertandingan ditutup dengan pengumuman tim juara dan pengumuman pemain terbaik. Karena keterbatasan waktu dan biaya, puncak pertandingan dan festivity dilakukan dengan sangat sederhana.

Berdasarkan uji coba skala besar, diperoleh data bahwa secara umum siswa merasa senang dengan model pembelajaran yang telah dilakukan. Hal ini dibuktikan dengan hasil angket yang disebar kepada 27 siswa diperoleh hasil rerata sebesar 9,14 dan masuk dalam kategori baik. Mayoritas siswa merasa senang melaksanakan pembelajaran. Namun yang patut dicatat, sebanyak sembilan anak atau 33,3\% menyatakan bahwa pembelajaran dengan model sport education tidak meningkatkan kualitas gerak atau kemampuan psikomotorik siswa.

Guru pendidikan jasmani berpendapat model sport education mudah dipelajari dan buku panduan sangat membantu dalam melaksanakan pembelajaran. Guru dapat secara fleksibel berkreasi sesuai dengan kondisi sekolah. Hasil instrumen yang diberikan kepada guru menunjukkan bahwa buku panduan masuk dalam kategori sangat baik dan model pembelajaran masuk dalam kategori sangat baik.

Masukan yang diberikan guru selama pelaksanaan uji coba skala besar antara lain: (1) Dalam RPP tidak dicantumkan kegiatan berdo'a sebelum dan sesudah pelajaran. Kegiatan tersebut harus dimasukkan dalam kaitannya dengan pendidikan karakter; (2) Buku panduan harus mencantumkan form contoh penilaian.

\section{Data Hasil Validasi Ahli}

Setelah draft awal tersusun, maka produk selanjutnya divalidasikan kepada seorang ahli pendidikan jasmani dan seorang praktisi penjas senior. Validasi bertujuan untuk menggali komentar dan saran perbaikan terhadap draft buku panduan yang telah di susun. Saran dan komentar diperoleh melalui diskusi secara lisan maupun saran tertulis. Validasi ahli dilakukan pada akhir bulan Maret hingga awal bulan April.
Tabel 1. Kategori Kecenderungan Validasi Ahli

\begin{tabular}{cccc}
\hline No & Skor & Frek. & Kategori \\
\hline 1 & $<20,1$ & 0 & Sangat Rendah \\
2 & $20,1-27,2$ & 0 & Rendah \\
3 & $27,3-32,2$ & 0 & Sedang \\
4 & $33,3-39,9$ & 0 & Tinggi \\
5 & $>39,9$ & 2 & Sangat Tinggi \\
& Jumlah & 2 & \\
\hline
\end{tabular}

Berdasarkan tabel tersebut, dengan rerata sebesar 43 dapat diketahui bahwa tanggapan ahli penjas dan praktisi penjas terhadap buku panduan pelaksanaan pembelajaran sport education masuk dalam kategori sangat tinggi. Maka dapat disimpulkan bahwa draft model buku layak untuk diuji cobakan dalam skala kecil dan besar.

Kualitas Draft Buku

Kualitas draft buku dan model pembelajaran sport education diukur melalui angket yang disebarkan kepada tiga orang guru penjas. Tiga orang guru penjas tersebut merupakan guru yang melaksanakan uji coba skala kecil dan skala besar.

Tabel 2. Kategori Kecenderungan Kualitas Draft Buku

\begin{tabular}{cccc}
\hline No & Skor & Frek & Kategori \\
\hline 1 & $<8,74$ & 0 & Sangat Rendah \\
2 & $8,75-11,24$ & 0 & Rendah \\
3 & $11,25-13,74$ & 1 & Sedang \\
4 & $13,75-16,24$ & 0 & Tinggi \\
5 & $>16,25$ & 2 & Sangat Tinggi \\
& Jumlah & 3 & \\
\hline
\end{tabular}

Berdasarkan tabel, dengan rerata sebesar 16 dapat diketahui bahwa tanggapan guru penjas terhadap kualitas buku panduan pelaksanaan pembelajaran sport education masuk dalam kategori sangat tinggi, yaitu sebesar 77\%. Maka dapat disimpulkan bahwa kualitas draft model buku panduan pelaksanaan pembelajaran berbasis kejuaraan masuk dalam kategori sangat tinggi.

\section{Efektivitas Model}

Efektivitas model diukur melalui angket yang disebar kepada tiga orang guru penjas yang melakukan uji coba skala kecil dan skala besar. 
Tabel 3. Kategori Kecenderungan Efektivitas Draft Buku

\begin{tabular}{cccc}
\hline No & Skor & Frek & Kategori \\
\hline 1 & $<8,74$ & 0 & Sangat Rendah \\
2 & $8,75-11,24$ & 0 & Rendah \\
3 & $11,25-13,74$ & 0 & Sedang \\
4 & $13,75-16,24$ & 0 & Tinggi \\
5 & $>16,25$ & 3 & Sangat Tinggi \\
& Jumlah & 3 & \\
\hline
\end{tabular}

Berdasarkan tabel tersebut, dengan rerata sebesar 35,6 dapat diketahui bahwa tanggapan guru penjas terhadap efektivitas model pembelajaran sport education masuk dalam kategori sangat tinggi, yaitu sebesar $100 \%$. Maka dapat disimpulkan bahwa efektivitas pelaksanaan model pembelajaran sport education masuk dalam kategori sangat tinggi.

\section{Respon Siswa}

Respon siswa di ukur dengan menggunakan angket. Berikut adalah persentase kecenderungan data angket yang dibagikan kepada siswa tentang respon siswa terhadap model pembelajaran.

Tabel 4. Distribusi Kecenderungan Respon Siswa

\begin{tabular}{cccc}
\hline No & Skor & Frek. & Kategori \\
\hline 1 & $<3,4$ & 0 & Sangat Rendah \\
2 & $3,5-4,14$ & 0 & Rendah \\
3 & $4,15-5,84$ & 0 & Sedang \\
4 & $5,85-7,4$ & 17 & Tinggi \\
5 & $>7,5$ & 76 & Sangat Tinggi \\
\hline
\end{tabular}

Pembahasan

Berdasarkan hasil penelitian, maka pemabahasan tentang data validitas, kualitas buku panduan dan model pembelajaran adalah sebagai berikut.

\section{Validasi Ahli Penjas dan Praktisi Penjas}

Validasi ahli penjas dan praktisi penjas terhadap buku panduan pelaksanaan pembelajaran sport education dengan rerata sebesar 43 masuk dalam kategori sangat tinggi. Skor validasi yang tinggi menggambarkan bahwa buku layak untuk digunakan dalam uji coba skala kecil dan skala besar.

Terdapat perubahan yang signifikan antara draft pada tahap sebelum validasi ahli dan setelah validasi ahli. Perubahan paling signifikan adalah perubahan istilah yang digunakan dalam buku panduan. Pada tahap sebelum validasi ahli, peneliti menggunakan istilah sport education. Istilah sport education adalah istilah yang diciptakan Daryl Siedentop dan telah secara familier digunakan di masyarakat pendidikan jasmani internasional. Setelah validasi ahli peneliti menggunakan istilah pembelajaran berbasis kejuaraan. Istilah pembelajaran berbasis kejuaraan digunakan peneliti karena dalam kata "kejuaraan" terdapat komponen-kompenen yang secara representatif menghadirkan key feature (kunci utama) dari kata sport. Kunci utama dalam sport education adalah musim, anggota tim, kompetisi formal, puncak pertandingan, catatan hasil dan perayaan hasil pertandingan. Kata "kejuaraan" hampir secara sempurna menghadirkan konsep sport dalam kata yang telah secara lazim digunakan orang Indonesia. Peneliti tidak menggunakan kata "Pendidikan Olahraga" karena konsep "Pendidikan Olahraga" di Indonesia sangat berbeda dengan konsep sport education karya Daryl Siedentop, sehingga dikhawatirkan menimbulkan kerancuan.

\section{Penilaian Guru Penjas terhadap Kualitas Buku Panduan}

Penilaian guru penjas terhadap kualitas buku panduan pelaksanaan pembelajaran sport education dengan rerata sebesar 16 masuk dalam kategori sangat tinggi. Guru pendidikan jasmani berpendapat buku panduan sangat membantu dalam melaksanakan pembelajaran. Guru dapat secara fleksibel berkreasi sesuai dengan kondisi sekolah. Buku panduan membimbing guru melalui langkah-langkah yang jelas dalam melaksanakan sport education.

\section{Penilaian Guru Penjas terhadap Efektivitas Model}

Penilaian guru penjas terhadap efektivitas model pembelajaran sport education berbasis kejuaraan dengan rerata sebesar 35,6 masuk dalam kategori sangat tinggi. Guru pendidikan jasmani berpendapat model sport education sangat menarik untuk digunakan dan mampu meningkatkan motivasi siswa. Pada tahun ajaran selanjutnya, guru yang bersangkutan akan mencoba menggunakan model sport education dengan waktu yang lebih panjang dan sistem kompetisi penuh. 
Tanggapan Siswa terhadap Pelaksanaan Pembelajaran

Tanggapan siswa terhadap pelaksanaan pembelajaran sport education rerata sebesar 9,06 masuk dalam kategori sangat tinggi. Penelitian menunjukkan bahwa sebelum pertandingan, siswa sangat bergairah menunggu hari pertandingan. Selama pertandingan, siswa merasa sangat senang dan menikmati penampilan tim nya, dan serta terus menerus membicarakan elemen-elemen dalam pertandingan tersebut. Secara umum, pertandingan mampu meningkatkan motivasi intrinsik siswa dalam mengikuti pembelajaran penjas.

Buku disusun dalam kata-kata yang mudah dipahami. Langka-langkah pembelajaran yang harus dilakukan di sampaikan secara runtut dan terperinci. Mengacu pada hasil analisis tersebut, maka buku panduan pelaksanaan pembelajaran sport education dengan judul "Panduan Pelaksanaan Pembelajaran Berbasis Kejuaraan" layak untuk digunakan sebagai sumber belajar.

\section{Simpulan dan Saran}

Simpulan

Buku panduan pelaksanaan pembelajaran sport education dikembangkan dengan menggunakan metode penelitian research and development yang diadopsi dari rancangan Borg \& Gall dan Sugiyono dengan beberapa modifikasi menjadi lima tahap. Tahap studi pendahuluan yang meliputi studi pustaka dan survei lapangan. Tahap desain produk yang terdiri dari tujuan pengembangan produk, cakupan materi, sasaran dan produk kemudian dituangkan dalam draft awal buku panduan. Tahap validasi oleh ahli dan praktisi guru penjas berpengalaman. Tahap uji coba dan revisi produk berdasarkan masukan dari validator, guru dan siswa tempat uji coba skala kecil dan besar. Tahap produk akhir merupakan tahap penyusunan buku panduan berdasarkan revisi-revisi pada tahap sebelumnya.

Buku disusun dalam tiga bab, yaitu Bab 1 tentang pengenalan pembelajaran berbasis kejuaraan. Bab 2 tentang tata laksana pembelajaran berbasis kejuaraan; dan Bab 3 penutup. Di dalamnya terdapat tiga tahap implementasi yaitu; perencanaan, pelaksanaan dan evaluasi.

Validitas, kualitas buku panduan dan model pembelajaran adalah sebagai berikut. Validasi ahli penjas dan praktisi penjas terhadap buku panduan pelaksanaan pembelajaran sport education dengan rerata sebesar 43 masuk dalam kategori sangat tinggi. Penilaian guru penjas terhadap kualitas buku panduan pelaksanaan pembelajaran sport education dengan rerata sebesar 16 masuk dalam kategori sangat tinggi Tanggapan siswa terhadap pelaksanaan pembelajaran sport education rerata sebesar 9,06 masuk dalam kategori sangat tinggi.

Buku panduan pelaksanaan pembelajaran sport education dengan judul "Panduan Pelaksanaan Pembelajaran Berbasis Kejuaraan" layak untuk digunakan sebagai sumber belajar.

Saran

Buku panduan pelaksanaan pembelajaran sport education dengan judul "Penduan Pelaksanaan Pembelajaran Berbasis Kejuaraan" disarankan kepada guru pendidikan jasmani di SMP sebagai alternatif pilihan dalam pembelajaran penjas.

Informasi keefektifan buku panduan dan model pembelajaran sport education masih sangat terbatas, terbuka peluang yang besar bagi peneliti untuk mengkaji lebih jauh tentang keefektifan buku panduan dan model pembelajaran.

Penyebaran penggunaan buku panduan secara massal dpat diupayakan melalui MGMP (Musyawarah Guru Mata Pelajaran) pendidikan jasmani SMP.

\section{Daftar Pustaka}

Alexander, K. \& Penney, D. (2005). Teaching under the influence: feeding games for understanding into the sport education development refinement cycle. Journal of physical education \& sport pedagogy, 10, 287-301.

BNSP. (2006). Panduan penyusunan kurikulum tingkat satuan pendidikan jenjang pendidikan dasar dan menengah. Jakarta: BNSP.

Borg, W.R. \& Gall, M.D. (1983). Educational research: An introduction, $\left(4^{\text {th }} \mathrm{ed}\right)$. New York: Longman.

Byra, M. (2006). Teaching styles and inclusive pedagogies. London: Sage.

Depdiknas. (2004). Dasar standarisasi profesi guru dan konseling. Jakarta: Depdiknas. 
Direktorat Pendidikan Lanjutan Pertama. (2004). Pedoman diagnostik potensi peserta didik. Jakarta: Direktorat Pendidikan Lanjutan Pertama, Depdiknas.

Furchan, Arief. (2005). Kurikulum berbasis kompetensi di perguruan tinggi agama Islam. Yogyakarta: Pustaka Pelajar.

Hastie P., Ojeda \& Luquin A.C. (2011). A review of research on Sport Education: 2004 to the present. Journal of physical education \& sport pedagogy, 16, 103132.

Ibrahim, Muslimin, dkk. (2000). Pembelajaran kooperatif. Surabaya: UNESA.

Kartadinata, S. (2004). Standar profesi bimbingan dan konseling. Bandung: Semiloka UPI.

Kemendikbud. (2012). Dokumen kurikulum 2013. Jakarta: Kementrian Pendidikan dan Kebudayaan.

(2013). Kurikulum 2013: Kompetensi dasar Sekolah Menengah Pertama (SMP) dan Madrasah Tsanawiyah (MTs). Jakarta: Kementrian Pendidikan dan Kebudayaan.

Kinchin G., Macphail, A., \& Chroinin, D. (2009). Pupils and teachers perceptions of a culminating festival within a sport education season in Irish primary schools. Journal of physical education \& sport pedagogy, 14, 391-406.

Mendiknas. (2003). Kurikulum berbasis kompetensi. Jakarta: Mendiknas.

(2006). Peraturan menteri pendidikan nasional nomor 22 tahun 2006. Jakarta: Mendiknas.

Metzler, M. (2000). Instructional models for physical education. Massachussetts: Allyn \& Bacon.

Monk. (2002). Psikologi perkembangan: pengantar dalam berbagai bagiannya. Yogyakarta: Gadjah Mada University Press.
Mulyasa, E. (2002). Kurikulum berbasis kompetensi: konsep, karakteristik, dan implementasi. Bandung: Remaja Rosdakarya.

Nuruddin Priya. B.S. (2011). Isu, tantangan dan masa depan pendidikan jasmani dan olahraga. Jurnal Ilmiah SPIRIT, 11, 1341.

Perlman, D. (2011). The influence of the sport education model on developing autonomous instruction. Journal of physical education \& sport pedagogy, 1, 1-13.

Puskur. (2007). Model kurikulum tingkat satuan pendidikan untuk Sekolah Dasar. Jakarta: Puskur Depdiknas.

Rahyubi, Heri. (2012). Teori-teori belajar dan aplikasi pembelajaran motorik: deskripsi dan tinjauan kritis. Bandung: Nusa Media.

Rukmana, Anik. (2008). Pembelajaran pendidikan jasmani di sekolah dasar. Jurnal pendidikan dasar. Bandung: Universitas Pendidikan Indonesia.

Rusman. (2011). Model-model pembelajaran: mengembangkan profesionalisme guru. Jakarta: PT Raja Grafindo Persada.

Sagala, Syaiful. (2012). Konsep dan makna pembelajaran. Bandung: Alfabeta.

Setiawan, Caly. (2004). Krisis identitas dan legitimasi dalam pendidikan jasmani. Jurnal pendidikan jasmani Indonesia, $1,1-7$.

Siedentop, D. (1994). Sport education: Quality $P E$ through positive sport experiences. Champaign, IL: Human Kinetics.

Siedentop, D., Hastie, P., Van Der Mars, H. (2004). Complete guide for sport education. Champaign, IL: Human Kinetics.

Stran, M. \& Curtner-Smith M. (2010): Impact of different types of knowledge on two preservice teachers' ability to learn and deliver the Sport education model. 
Journal of physical education \& sport pedagogy, 15, 243-256.

Sugiyono. (2008). Metode penelitian kuantitatif, kualitatif dan $R$ and $D$. Jakarta: Alfhabeta.

Sujadi. (2002). Metodologi penelitian pendidikan. Jakarta: Rineka cipta.

Suparlan. (2001). Menjadi guru efektif. Yogyakarta: Hikayat Publishing.

Surya, M. (2004). Psikologi pembelajaran dan pengajaran. Bandung: Pustaka Bani Quraisy.
Utama, Bandi. (2011). Pelatihan penyusunan model sport education sebagai upaya meningkatkan kualitas pembelajaran pendidikan jasmani di sekolah. Diambil pada tanggal 10 September 2013, dari http://staff.uny.ac.id/sites/default/files/p engabdian/am-bandi-utama-mpd/2artikel-ppm-bandi-utama-2011.pdf

Wallhead, T. \& O'Sullivan, M. (2005). Sport education: Physical education for the new millennia. Physical education and sport pedagogy, 10, 181-210.

Yusuf, S. (2004). Psikologi perkembangan anak dan remaja. Bandung: PT Remaja Rosdakarya. 